\title{
Polymorphisms in DNA repair genes: link with biomarkers of the CBMN cytome assay in hospital workers chronically exposed to low doses of ionising radiation
}

\author{
Mirta Milić1,4, Ružica Rozgaj ${ }^{1}$, Vilena Kašuba ${ }^{1}$, Ana-Marija Jazbec ${ }^{2}$, Boris Starčević ${ }^{3}$, Barnaba \\ Lyzbicki ${ }^{4}$, Gloria Ravegnini ${ }^{4}$, Corrado Zenesini ${ }^{5}$, Muriel Musti ${ }^{5}$, Patrizia Hrelia ${ }^{4}$, \\ and Sabrina Angelini ${ }^{4}$ \\ Institute for Medical Research and Occupational Health ${ }^{1}$, Faculty of Forestry, University of Zagreb' ${ }^{2}$, University \\ Hospital Dubrava, Department of invasive cardiology ${ }^{3}$ Zagreb, Croatia, Department of Pharmacy and Biotechnology, \\ University of Bologna ${ }^{4}$, Department of Public Health, Epidemiological Service, Local Health Authority of Bologna , \\ Bologna, Italy
}

[Received in April 2015; CrossChecked in April 2015; Accepted in June 2015]

Individual sensitivity to ionising radiation (IR) is the result of interaction between exposure, DNA damage, and its repair, which is why polymorphisms in DNA repair genes could play an important role. We examined the association between DNA damage, expressed as micronuclei (MNi), nuclear buds (NBs), and nucleoplasmic bridges (NPBs) and single nucleotide polymorphisms in selected DNA repair genes (APE1, hOGG1, XRCC1, XRCC3, XPD, PARP1, MGMT genes; representative of the different DNA repair pathways operating in mammals) in 77 hospital workers chronically exposed to low doses of IR, and 70 matched controls. A significantly higher MNi frequency was found in the exposed group (16.2 \pm 10.4 vs. $11.5 \pm 9.4 ; P=0.003$ ) and the effect appeared to be independent from the principal confounding factor. Exposed individuals with $h O G G 1, X R C C 1, P A R P 1$, and $M G M T$ wild-type alleles or APEXl, as well as XPD (rs13181) heterozygous showed a significantly higher MNi frequency than controls with the same genotypes. Genetic polymorphism analysis and cytogenetic dosimetry have proven to be a powerful tool complementary to physical dosimetry in regular health surveillance programmes.

KEY WORDS: genotype analysis; micronucleus; nuclear bud; nucleoplasmic bridge; occupational exposure

The health consequences of continuous exposure to low doses of ionising radiation (IR) are still a topic of great scientific interest. Medical workers are the most commonly studied group among chronically exposed professionals, with regular medical surveillance and obligatory dosimetry. The duration and amount of received radiation have significantly decreased over the last decades, with received doses well below the allowable limits of $20 \mathrm{mSv}$ per year. However, most studies on occupationally exposed subjects have shown an increase in genetic damage after chronic exposure to IR low doses, without evidence of any doseeffect relationship. Nevertheless, recent literature, including a paper on as many as 400.000 nuclear power plant workers, shows significant correlation between accumulated doses and risk of tumour development (1-4).

The cytokinesis-blocked micronucleus (CBMN) assay has been widely used to evaluate DNA damage after occupational, therapeutic or accidental exposure to IR, as well as to assess in vitro radiosensitivity and cancer susceptibility. For instance, in Belgium and Croatia, the

Correspondence to: Mirta Milić, PhD, Institute for Medical Research and Occupational Health, Mutagenesis Unit, Zagreb, Croatia; Phone: +385 1 4682 633, Fax: +385 14673 303; E-mail address: mmilic@imi.hr
CBMN assay is regularly applied in the biomonitoring of workers exposed to IR higher than or expected to reach $20 \mathrm{mSv}$ (5). In recent years, the CBMN assay has evolved into the novel cytome assay, where every cell is scored for its damage and mitotic status (6). Originally, the CBMN assay was developed to measure micronuclei (MNi) - whole chromosomes or acentric chromosome fragments that lag behind during anaphase and are not distributed to the main nuclei. Subsequently it was observed that the CBMN assay may also measure other forms of damage, such as nuclear buds (NBs) and nucleoplasmic bridges (NPBs). NBs have been proposed as markers of gene amplification and/or altered gene dosage; NPBs provide a measure of chromosome rearrangement, or DNA misrepair, and may break to form MNi (6). The CBMN assay also allows one to calculate the nuclear division index (NDI), providing information on a cell cycle's delay with regard to exposure.

Individual sensitivity to IR exposure is the result of a close interaction between DNA damage and DNA repair. Several authors have already described the association between genetic damage, IR exposure, and polymorphisms in DNA repair genes (7-10). 
To the best of our knowledge, this is the first study to evaluate if biomarkers of the $\mathrm{CBMN}$ cytome assay $(\mathrm{MNi}$, NPBs, NBs, and NDI) could be sensitive enough to evaluate the impact of occupational exposure to IR low doses. Moreover, we investigated the possible influence on biomarkers of the CBMN cytome assay of a comprehensive panel of polymorphisms in DNA repair genes. Included in the analysis were polymorphisms in the APE1, hOGG1, $X R C C 1, X R C C 3, X P D, P A R P 1$, and $M G M T$ genes, representative of the different DNA repair pathways operating in mammals.

\section{MATERIALS AND METHODS}

\section{Study population}

The study included 77 medical workers occupationally exposed to low doses of IR, and 70 controls who had never been occupationally exposed to IR or other known carcinogenic agents. All of the subjects gave their written consent after being informed on the study scope and experimental details. The study followed the guidelines of the Declaration of Helsinki regarding medical research involving human subjects, and was approved by an ethics committee. Standardised questionnaires were administered to all of the participants to determine their sociodemographic characteristics, medical history (e.g. history of medical treatments, radiography, recent vaccination, severe infections, or viral diseases over the past six months, presence of known inherited genetic disorders and chronic diseases, family history of cancer), and individual life styles [e.g. smoking, alcohol consumption, dietary habits, including deficient or peculiar habits (e.g. vegetarian or vegans), or intake of multi-vitamins supplements, and use of contraceptive]. Exclusion criteria included the use of any therapeutic drugs, radiotherapy, diagnostic X-rays undergone 12 months prior to sampling, which could have significantly contributed to the received dose and/or genetic damage. For medical workers, the questionnaires covered the duration of occupational exposure to IR. Selected demographic characteristics of the study population are reported in Table 1. Among the medical workers, we distinguished between seven different working tasks: gastroenterologist, interventional cardiologist, anaesthesiologists, surgeons, radiologists, and engineers of radiology. All of the IR exposed workers were under medical surveillance and regular film dosimetry, however according to the written consent provide to the subjects, we only know the annual dose received did not exceed the limit of $20 \mathrm{mSv}$ per year.

Venous blood was obtained from each subject and transferred to the laboratory within a few hours for subsequent $\mathrm{CBMN}$ assay and genotype analysis.
Table 1 Demographic characteristics of the study population

\begin{tabular}{lccc}
\hline & Exposed & Controls & Total \\
\hline Sample size (n) & 77 & 70 & 147 \\
\hline Sex & & & \\
Female n (\%) & $46(59.7)$ & $26(37.1)$ & $72(49.0)$ \\
Male n (\%) & $31(40.3)$ & $44(62.9)$ & $75(51.0)$ \\
\hline Age & & & \\
mean \pm SD & $42.2 \pm 10.6$ & $40.8 \pm 10.4$ & $41.5 \pm 10.5$ \\
range & $23-69$ & $20-60$ & $20-69$ \\
\hline Smoking status & & & \\
Never (\%) & $47(61.0)$ & $50(71.4)$ & $97(66.0)$ \\
Current (\%) & $30(39.0)$ & $20(28.6)$ & $50(34.0)$ \\
\hline $\begin{array}{l}\text { Years of exposure } \\
\text { mean } \pm \text { SD }\end{array}$ & $13.7 \pm 8.9$ & & \\
range & $1-38$ & - & -
\end{tabular}

*Significantly lower compared to controls $\mathrm{P}=0.032$ (Wilcoxon test)

\section{CBMN cytome assay}

Cultures for the CBMN assay were set up in triplicate. Lymphocytes were cultured in RPMI 1640 medium (Gibco, Paisley, UK), supplemented with $1 \%$ of phytohaemagglutinin, (Apogent, USA), $20 \%$ of foetal calf serum (Gibco), and $1 \%$ penicillin-streptomycin solution (Sigma-Aldrich, St Louis, MO, USA) and incubated at $37^{\circ} \mathrm{C}$ in humidified $5 \%$ $\mathrm{CO}_{2}$ atmosphere for $72 \mathrm{~h}$. After $44 \mathrm{~h}$, all cultures were supplemented with cytochalasin B (Sigma; final concentration $6 \mu \mathrm{g} \mathrm{mL}^{-1}$ ). At the end of the incubation period, lymphocytes were subjected to a mild hypotonic treatment, fixed, and stained according to Kapka et al. (11). One thousand binucleated lymphocytes with well-preserved cytoplasm per subject were analysed. The criteria for analysis of MNi, NPBs, and NBs were as described by Fenech et al. (12). NDI was calculated according to the formula $\mathrm{NDI}=\left(1 \mathrm{M}_{1}+2 \mathrm{M}_{2}+3 \mathrm{M}_{3}+4 \mathrm{M}_{4}\right) / 1000$ cells where $\mathrm{M}_{1}-\mathrm{M}_{4}$ indicates lymphocytes with 1 to 4 nuclei (13).

\section{DNA isolation}

Genomic DNA was isolated from EDTA-anticoagulated whole blood using standard sodium perchlorate/chloroform extraction procedures or the QIAamp DNA Blood kit (Qiagen, Hilden, Germany) as recommended by the manufacturer. For genotype analysis, DNA samples were diluted and stored as $10 \mathrm{ng} \mu \mathrm{L}^{-1}$ aliquots at $-20{ }^{\circ} \mathrm{C}$. Genotyping was performed by PCR-based assays: RFLP and/or real-time (Table 2) $(9,14,15)$. Negative controls were included in each reaction as quality control. Genotyping by real-time PCR was performed by the 5 '-nuclease allelic discrimination assay (TaqMan ${ }^{\circledR}$, Applied Biosystems, Foster City, CA, USA), according to the manufacturer's instruction. Genotype screening was carried out simultaneously in a blinded manner to work allocation (exposed, non-exposed). Genotype results were regularly confirmed by repetition of $90 \%$ of the samples. 
Table 2 Details on investigated SNPS in DNA repair genes

\begin{tabular}{|c|c|}
\hline $\begin{array}{l}\text { GENE } \\
\text { rs unique code [base and amino acid change] }\end{array}$ & METHOD $^{[A]}$ \\
\hline \multicolumn{2}{|l|}{ APEX1 } \\
\hline rs1130409 [gaT > gaG; Asp148Glu] & $\begin{array}{l}\text { RFLP [Hu et al., 2002] (14) } \\
\text { RT TaqMan assay C } 8921503 \quad 10\end{array}$ \\
\hline \multicolumn{2}{|l|}{ hOGG1 } \\
\hline rs1052133 [tCc > tGc; Ser326Cys] & $\begin{array}{l}\text { RFLP [Godderis et al., 2006] (15) } \\
\text { RT TaqMan assay C_3095552_1 }\end{array}$ \\
\hline \multicolumn{2}{|l|}{ XPD } \\
\hline $\begin{array}{l}\text { rs1799793 [Gac > Aag; Asp312Asn] } \\
\text { rs13181 [Aag > Cag; Lys751Gln] }\end{array}$ & $\begin{array}{l}\text { RT TaqMan assay C_3145050_10 } \\
\text { RFLP [Angelini et al., 2005] (8) } \\
\text { RT TaqMan assay C_3145033_10 }\end{array}$ \\
\hline \multicolumn{2}{|l|}{ XRCC1 } \\
\hline rs861539 [cAg > cGg; Gln399Arg] & $\begin{array}{l}\text { RFLP [Angelini et al., 2005] (8) } \\
\text { RT TaqMan assay C } 62256410\end{array}$ \\
\hline \multicolumn{2}{|l|}{$\mathrm{XRCC3}$} \\
\hline rs861539 [aCg > aTg; Thr241Met] & $\begin{array}{l}\text { RFLP [Angelini et al., 2005] (8) } \\
\text { RT TaqMan assay C } 3145033 \quad 10\end{array}$ \\
\hline \multicolumn{2}{|l|}{ PARP1 } \\
\hline rs1136410 [gTg > gCg; Val762Gly] & RT TaqMan assay C_1515368_1_ \\
\hline \multicolumn{2}{|l|}{ MGMT } \\
\hline rs12917 [Ctt > Ttt; Leu115Phe] & RT TaqMan assay C_3157955_10 \\
\hline
\end{tabular}

\section{Statistical analysis}

The Wilcoxon rank-sum test was used to test the difference in $\mathrm{MNi}, \mathrm{NB}$, and NPB frequency between exposed workers and controls. The association between $\mathrm{MNi}, \mathrm{NB}$, and NPB frequency and the various genotypes was tested by Kruskal-Wallis test. The distribution of genotypes was tested for Hardy-Weinberg (HW) equilibrium using the online HW test tool offered by the Institute for Human Genetics, Technical University Munich, Germany. Linear regression analysis was applied to assess the correlation between years of IR exposure and MNi, NBs, and NPBs in the exposed workers. The Poisson regression analysis was applied to evaluate the influence of age, sex, smoking status, and working task on MNi, NPBs, and NBs in the overall population and in both groups separately. The level of significance was set at $P<0.05$; statistical analysis was conducted using Stata Intercooled version 11.0 (16).

\section{RESULTS}

The principal demographic characteristics of the study population, both overall and by group are reported in Table 1. In summary, age distribution was similar in the two groups ( $P=0.212)$; while sex was significantly different, as females were over-represented in the IR-exposed individuals than controls (59.7 vs. $37.1 \%, P=0.006)$. Regarding smoking status, $39.0 \%$ of the exposed workers and $28.6 \%$ controls were smokers at the time of sampling. No difference was observed between the two groups in terms of years of smoking or daily cigarette consumption, all being mild smokers (less than 10 cigarettes per day).

\section{CBMN assay}

Results of CBMN cytome assay (MNi, NPB, NB frequencies and NDI) are presented in Table 3. Of the four analysed parameters, only MNi frequency was significantly higher in the exposed workers than in controls $(P=0.003)$. The frequencies of the other parameters were similar between the exposed and controls. The range of IR exposure duration in radiological workers, i.e. years of employment, was 1-38 (Table 1). Linear regression analysis revealed a significant association between years of employment and $\mathrm{MNi}(\beta=0.403, P=0.003$; Figure $1 \mathrm{~A})$ and NBs $(\beta=0.075$, $P=0.027$; Figure $1 \mathrm{~B})$, whereas no association emerged with NPBs $(\beta=0.024, P=0.230)$.

The results of Poisson regression analysis reporting the influence of confounding factors, which included age, sex, and smoking status on MNi, NPBs, and NBs, are reported in Table 3 to Table 6 respectively. With regard to MNi (Table 4 ), an increase in age resulted in a significant increase in MNi frequency both in controls and exposed workers $(P<0.0001$ for both). Sex exerted a significant influence on the yield of MNi only in controls, with the frequency being 
Table 3 Results of micronucleus assay in the study groups

\begin{tabular}{lcc}
\hline & Exposed & Controls \\
\hline Micronuclei & & \\
Mean \pm SD & $16.2 \pm 10.4^{*}$ & $11.5 \pm 9.4$ \\
(Range) & $1-47$ & $0-37$ \\
\hline Nucleoplasmatic bridges & & \\
Mean \pm SD & $0.9 \pm 1.5$ & $1.7 \pm 4.0$ \\
(Range) & $0-8$ & $0-30$ \\
\hline Nuclear buds & & \\
Mean \pm SD & $1.7 \pm 2.6$ & $2.2 \pm 3.5$ \\
(Range) & $0-15$ & $0-23$ \\
\hline Nuclear division index & & \\
Mean \pm SD & $1.8 \pm 0.3$ & $1.9 \pm 0.4$ \\
(Range) & $1.2-2.3$ & $0-2.7$
\end{tabular}

${ }^{*}$ Significantly higher compared to controls $\mathrm{P}=0.003$ (Wilcoxon test)

higher in females as compared to males $(P=0.002)$. Smoking status significantly influenced MNi frequency in both study groups, however at an opposite trend: being higher in current smokers compared to non-smokers in the IR exposed group, whereas in controls current smokers were characterized by lower MNi frequency than those that had never smoked $(P<0.0001$ for both). Regarding NPB frequency (Table 5), only sex exerted a significant influence in both study groups. In particular, NPB frequency was significantly higher in males compared to females $(P=0.004$ in IR exposed; $P=0.015$ in controls). In the control group, we also observed a significant influence of age $(P<0.0001)$. As regard to NBs (Table 6), in the IR exposed group we observed a significant age-dependent effect $(P=0.001)$. Non-smokers were characterised by a significantly higher NB frequency as compared to current smokers $(P=0.002)$. In the control group, we observed the influence of sex, with NBs being significantly higher in males compared to females $(P=0.008)$, and a significant age-dependent effect $(P=0.008)$.

Poisson regression analysis applied to the overall study population highlighted the significant influence of age on MNi, NPBs, and NBs. In all three instances, an increase of age was associated with a significant increase of the observed frequency of DNA damage $(P<0.0001$ for all). With regard to sex, MNi frequency was lower in males, although not significantly $(P=0.064)$, whereas the opposite results were observed for NPB and NB frequency, being significantly higher in males than female $(P<0.0001$ and $P=0.013$ respectively). We observed a significant effect of smoking status only in NBs; surprisingly this biomarker was higher in non-smokers compared to active smokers $(P<0.0001)$. Interestingly, when dividing smokers into two classes (0-10 and $>10$ years) of smoking habits - a significant effect was observed only in the second group. In particular, individuals who smoked for more than 10 years exhibited a significantly lower NBs frequency (IRR $0.579,95 \%$ CI 0.403-0.833; $P=0.003$ ), whereas no effect was observed in those who smoked less than 10 years.
Table 4 Poisson regression analysis of confounding factors on MNi frequencies

\begin{tabular}{|c|c|c|c|}
\hline Confounding factors ${ }^{a}$ & IRR & $P$ & $95 \%$ CI \\
\hline \multicolumn{4}{|l|}{ All } \\
\hline Age (years) & 1.020 & $<0.0001$ & $1.016-1.025$ \\
\hline Sex $(0,1)$ & 0.918 & 0.064 & $0.839-1.004$ \\
\hline Smoking status $(0,1)$ & 1.047 & 0.335 & $0.954-1.149$ \\
\hline Exposure (years) & 1.332 & $<0.0001$ & $1.214-1.460$ \\
\hline \multicolumn{4}{|l|}{ Controls } \\
\hline Age (years) & 1.018 & $<0.0001$ & $1.011-1.026$ \\
\hline Sex $(0,1)$ & 0.801 & 0.002 & $0.696-0.923$ \\
\hline Smoking status $(0,1)$ & 0.729 & $<0.0001$ & $0.612-0.867$ \\
\hline \multicolumn{4}{|l|}{ Exposed workers } \\
\hline Age (years) & 1.020 & $<0.0001$ & $1.015-1.026$ \\
\hline $\operatorname{Sex}(0,1)$ & 0.971 & 0.621 & $0.864-1.091$ \\
\hline Smoking status $(0,1)$ & 1.227 & $<0.0001$ & $1.094-1.376$ \\
\hline
\end{tabular}

Table 5 Poisson regression analysis of confounding factors on NPBs frequencies

\begin{tabular}{|c|c|c|c|}
\hline Confounding factors ${ }^{a}$ & IRR & $P$ & $95 \%$ CI \\
\hline \multicolumn{4}{|l|}{ All } \\
\hline Age (years) & 1.031 & $<0.0001$ & $1.016-1.046$ \\
\hline $\operatorname{Sex}(0,1)$ & 1.771 & $<0.0001$ & $1.290-2.433$ \\
\hline Smoking status $(0,1)$ & 0.863 & 0.377 & $0.623-1.196$ \\
\hline Exposure (years) & 0.621 & 0.002 & $0.458-0.843$ \\
\hline \multicolumn{4}{|l|}{ Controls } \\
\hline Age (years) & 1.049 & $<0.0001$ & $1.029-1.070$ \\
\hline $\operatorname{Sex}(0,1)$ & 1.700 & 0.015 & $1.111-2.603$ \\
\hline Smoking status $(0,1)$ & 1.013 & 0.951 & $0.660-1.557$ \\
\hline \multicolumn{4}{|l|}{ Exposed workers } \\
\hline Age (years) & 1.008 & 0.457 & $0.987-1.030$ \\
\hline Sex $(0,1)$ & 2.021 & 0.004 & $1.258-3.246$ \\
\hline Smoking status $(0,1)$ & 0.718 & 0.189 & $0.439-1.176$ \\
\hline
\end{tabular}

Table 6 Poisson regression analysis of confounding factors on $N B$ s frequencies

\begin{tabular}{lccc}
\hline Confounding factors & IRR & $\boldsymbol{P}$ & $\mathbf{9 5} \% \mathbf{C I}$ \\
\hline All & & & \\
\hline Age (years) & 1.025 & $<0.0001$ & $1.013-1.037$ \\
\hline Sex $(0,1)$ & 1.368 & 0.013 & $1.069-1.751$ \\
\hline Smoking status $(0,1)$ & 0.597 & $<0.0001$ & $0.448-0.795$ \\
\hline Exposure (years) & 0.841 & 0.164 & $0.660-1.073$ \\
\hline Controls & & & \\
\hline Age (years) & 1.023 & 0.008 & $1.006-1.040$ \\
\hline Sex (0,1) & 1.635 & 0.008 & $1.136-2.353$ \\
\hline Smoking status $(0,1)$ & 0.703 & 0.088 & $0.469-1.054$ \\
\hline Exposed workers & & & \\
\hline Age (years) & 1.029 & 0.001 & $1.012-1.047$ \\
\hline Sex (0,1) & 1.166 & 0.396 & $0.817-1.663$ \\
\hline Smoking status $(0,1)$ & 0.530 & 0.002 & $0.354-0.795$ \\
\hline IRR: Incidence Rate Ration & & &
\end{tabular}

IRR: Incidence Rate Ratio

${ }^{a}$ Sex: 0-Female, 1-Male; Smoking status: 0-Never, 1-Current 

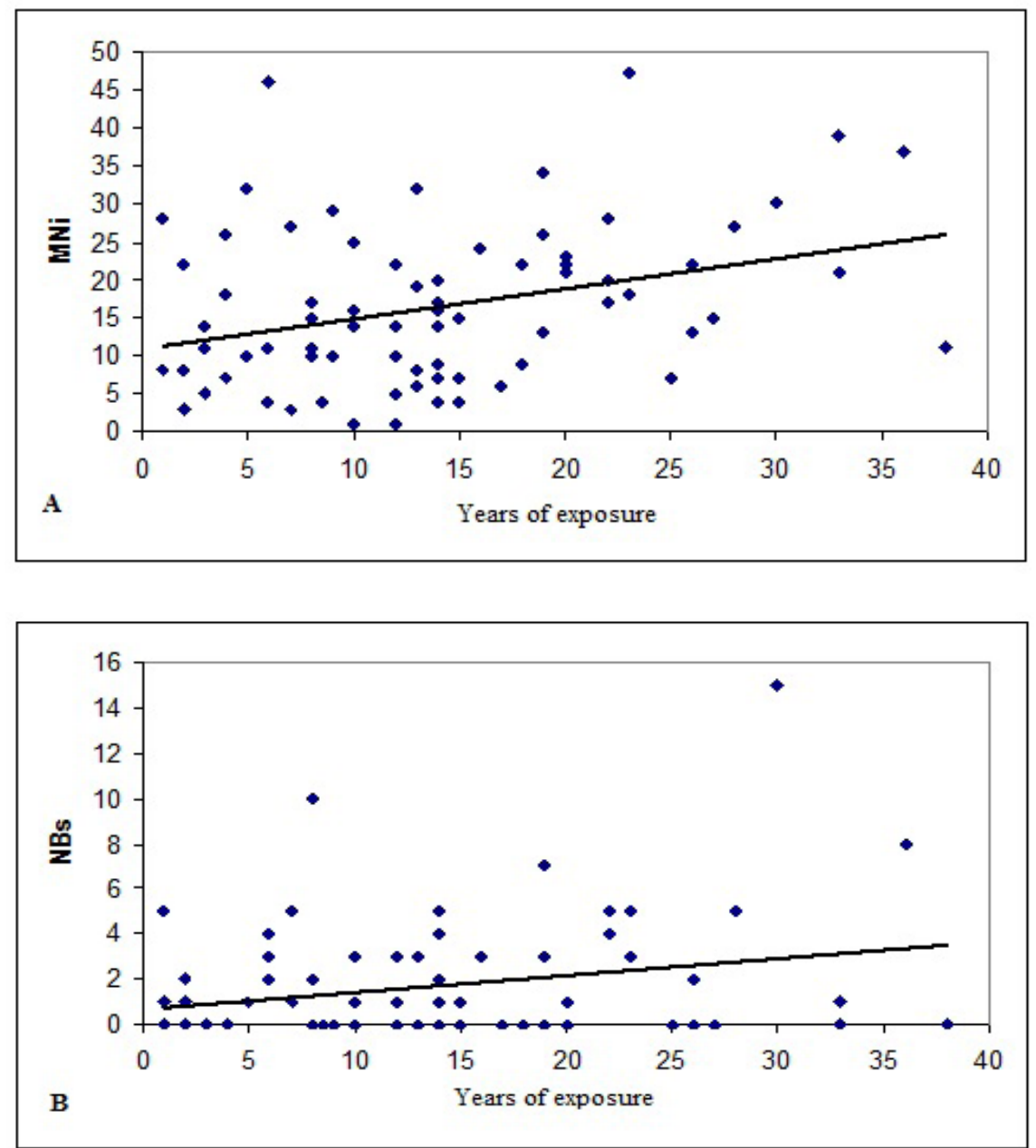

Figure 1 Relationship between DNA damage, assessed as micronuclei [MNi (A)] and nuclear buds [NBs (B)] in peripheral blood lymphocytes, and years of exposure to ionising radiation. The thick line represents the linear regression analysis of the data

With regard to exposure, Poisson analysis revealed that an increase in the years of IR exposure was associated with a significant increase in MNi frequency $(P<0.0001)$ and surprisingly a significant decrease of NPBs $(P=0.002)$. No effect of years of exposure on NBs was observed.

Genotype distribution and influence on biomarkers of the cytome assay

Details on the investigated SNPs in DNA repair genes are represented in Table 2. Genotype distribution of the eight studied DNA repair genes among the different study groups and in the overall population is presented in Table 7. Frequencies of the variant allele observed in our study were consistent with those reported in the publicly available database NCBI (dbSNP) for Caucasians. Deviation from the HW equilibrium was observed for one SNP in the IR exposed group (XPD rs13181); departure from HW equilibrium was not observed for any other SNPs in any of the studied group, or in the overall population. Allele frequencies were similar between the IR exposed and controls, with the exception of $h O G G 1$ rs 1052133 and
PARP1 rs1136410 SNPs. To be more precise, the $h O G G 1$ variant allele and $P A R P 1$ wild-type allele were significantly underrepresented in controls compared to IR exposed ( $P=0.0017$, and $P=0.039$ respectively).

Distribution of MNi, NPBs and NBs by DNA repair genotypes and exposure status are shown in Table 8 to Table 10 respectively. For several genes, due to the small number of individuals homozygous for the variant allele, the approach was to group them together with heterozygous in order to increase statistical power. Among the controls, PARP1 wild type allele was associated with significantly higher NBs compared to the combined homozygous SNP plus heterozygous genotype ( $2.5 \pm 3.0$ vs. $1.0 \pm 1.4, P=0.044$; Table 9). In the IR exposed group, the same genotype was also significantly associated with higher NPBs $(1.2 \pm 1.7 v s$. $0.4 \pm 0.8, P=0.027$; Table 10). No detectable influence of other genotypes on $\mathrm{MNi}$, NBs or NPBs was observed within the two groups. When we compared IR exposed workers with controls, a significantly higher MNi frequency was found in radiological workers homozygous wild-type for the hOGG1, XRCC1, XRCC3, MGMT1, and PARP1 compared to controls with the same genotypes (Table 8). 
Table 7 Genotype distribution, allele frequency and Hardy-Weinberg equilibrium of the investigated SNPs in DNA repair genes

\begin{tabular}{|c|c|c|c|}
\hline Genotype $^{*}$ & Exposed $(n=77)$ & Controls $(n=56)^{* *}$ & Total $(n=133)$ \\
\hline \multicolumn{4}{|c|}{ APEX1 rs1130409 } \\
\hline 0 & $26(33.8)$ & $19(33.9)$ & $45(33.8)$ \\
\hline 1 & $35(45.5)$ & $27(48.2)$ & $62(46.6)$ \\
\hline 2 & $\begin{array}{c}16(20.7) \\
q=0.44 ; P_{H W E}=0.509\end{array}$ & $\begin{array}{c}10(17.9) \\
q=0.42 ; P_{H W E}=0.939 \\
\text { Pafd }=0.802\end{array}$ & $\begin{array}{c}26(19.6) \\
q=0.43 ; P_{H W E}=0.578\end{array}$ \\
\hline \multicolumn{4}{|c|}{ hOGG1 rs1052133 } \\
\hline 0 & $38(49.3)$ & $42(75.0)$ & $80(60.1)$ \\
\hline 1 & $34(44.1)$ & $14(25.0)$ & $48(36.1)$ \\
\hline 2 & $\begin{array}{c}5(6.6) \\
q=0.29 ; P_{H W E}=0.285\end{array}$ & $\begin{array}{c}0(0.0) \\
q=0.12 ; P_{H W E}=0.473 \\
P a f d=0.0017\end{array}$ & $\begin{array}{c}5(3.8) \\
q=0.22 ; P_{H W E}=0.501\end{array}$ \\
\hline \multicolumn{4}{|c|}{ XPD rs1799793 } \\
\hline 0 & $31(40.3)$ & $17(30.4)$ & $48(36.1)$ \\
\hline 1 & $33(42.8)$ & $33(58.9)$ & $66(49.6)$ \\
\hline 2 & $\begin{array}{c}13(16.9) \\
q=0.38 ; P_{H W E}=0.413\end{array}$ & $\begin{array}{c}6(10.7) \\
q=0.40 ; P_{H W E}=0.091 \\
P a f d=0.758\end{array}$ & $\begin{array}{c}19(14.3) \\
q=0.39 ; P_{H W E}=0.628\end{array}$ \\
\hline \multicolumn{4}{|c|}{ XPD rs13181 } \\
\hline 0 & $32(41.6)$ & $15(27.2)$ & $47(35.3)$ \\
\hline 1 & $27(35.1)$ & $33(58.9)$ & $60(45.1)$ \\
\hline 2 & $\begin{array}{c}18(23.3) \\
q=0.41 ; P_{H W E}=0.016\end{array}$ & $\begin{array}{c}8(13.9) \\
q=0.44 ; P_{H W E}=0.140 \\
P a f d=0.643\end{array}$ & $\begin{array}{c}26(19.6) \\
q=0.42 ; P_{H W E}=0.389\end{array}$ \\
\hline \multicolumn{4}{|c|}{ XRCC1 rs861539 } \\
\hline 0 & $31(40.2)$ & $22(39.3)$ & $53(39.9)$ \\
\hline 1 & $41(53.2)$ & $25(44.6)$ & $66(49.6)$ \\
\hline 2 & $\begin{array}{c}5(6.6) \\
q=0.33 ; P_{H W E}=0.076\end{array}$ & $\begin{array}{c}9(16.1) \\
q=0.38 ; P_{H W E}=0.674 \\
P a f d=0.374\end{array}$ & $\begin{array}{c}14(10.5) \\
q=0.35 ; P_{H W E}=0.322\end{array}$ \\
\hline \multicolumn{4}{|c|}{ XRCC3 rs861539 } \\
\hline 0 & $23(29.9)$ & $23(42.6)$ & $46(35.1)$ \\
\hline 1 & $38(49.3)$ & $25(46.3)$ & $63(48.1)$ \\
\hline 2 & $\begin{array}{c}16(20.8) \\
q=0.45 ; P_{H W E}=0.967\end{array}$ & $\begin{array}{c}6(11.1) \\
q=0.34 ; P_{H W E}=0.838 \\
P a f d=0.070\end{array}$ & $\begin{array}{c}22(16.8) \\
q=0.41 ; P_{H W E}=0.956\end{array}$ \\
\hline \multicolumn{4}{|c|}{ PARP1 rs1136410 } \\
\hline 0 & $55(71.4)$ & $33(58.9)$ & $88(66.2)$ \\
\hline 1 & $21(27.3)$ & $18(32.1)$ & $39(29.3)$ \\
\hline 2 & $\begin{array}{c}1(1.3) \\
q=0.15 ; P_{H W E}=0.520\end{array}$ & $\begin{array}{c}5(9.0) \\
q=0.25 ; P_{H W E}=0.285 \\
P a f d=0.039\end{array}$ & $\begin{array}{c}6(4.5) \\
q=0.19 ; P_{H W E}=0.534\end{array}$ \\
\hline \multicolumn{4}{|c|}{ MGMT rs12917 } \\
\hline 0 & $56(72.7)$ & $39(69.6)$ & $95(71.4)$ \\
\hline 1 & $18(23.4)$ & $16(28.6)$ & $34(25.6)$ \\
\hline 2 & $\begin{array}{c}3(3.9) \\
q=0.16 ; P_{H W E}=0.328\end{array}$ & $\begin{array}{c}1(1.8) \\
q=0.16 ; P_{H W E}=0.658 \\
P a f d=0.914\end{array}$ & $\begin{array}{c}4(3.0) \\
q=0.16 ; P_{H W E}=0.655\end{array}$ \\
\hline
\end{tabular}

*0=homozygous wild-type (wt); $1=$ Heterozygous (HE); 2=homozygous polymorphic (SNP) $q=$ frequency of the $S N P$

$P_{H W E}=$ P-value of the Hardy-Weinberg Equilibrium

$P a f d=\mathrm{P}-$ value of the allele frequency difference between controls and IR exposed

**14 samples are missing due to lack of biological material 
Milić M, et al. Polymorphisms in DNA repair genes: CBMN cytome assay in workers chronically exposed to low doses of ionising radiation Arh Hig Rada Toksikol 2015;66:109-120

Table 8 Mean MNi frequencies in the study population subdivided by exposure status and genotype distribution

\begin{tabular}{|c|c|c|c|c|c|c|}
\hline \multicolumn{4}{|c|}{ Exposed $(n=77)$} & \multicolumn{3}{|c|}{ Controls $(\mathrm{n}=56)$} \\
\hline Gene* & Subject (n) & Mean \pm SD & $95 \%$ CI & Subject (n) & Mean \pm SD & $95 \%$ CI \\
\hline \multicolumn{7}{|c|}{ APEX1 rs1130409 } \\
\hline 0 & 26 & $15.1 \pm 10.2$ & $11.0-19.2$ & 19 & $11.0 \pm 10.3$ & $6.0-16.0$ \\
\hline 1 & 35 & $17.3 \pm 11.2^{\mathrm{a}}$ & $13.5-21.1$ & 27 & $10.3 \pm 8.8$ & $6.8-13.8$ \\
\hline 2 & 16 & $15.5 \pm 9.5$ & $10.4-20.6$ & 10 & $12.2 \pm 7.1$ & $7.1-17.3$ \\
\hline \multicolumn{7}{|c|}{ hOGG1 rs1052133 } \\
\hline 0 & 38 & $15.8 \pm 10.2^{b}$ & $12.4-19.1$ & 42 & $10.6 \pm 9.2$ & $7.7-13.4$ \\
\hline $1+2$ & 39 & $16.6 \pm 10.8$ & $13.1-20.1$ & 14 & $11.7 \pm 8.6$ & $6.7-16.7$ \\
\hline \multicolumn{7}{|c|}{ XPD rs1799793 } \\
\hline 0 & 31 & $16.5 \pm 11.1$ & $12.4-20.6$ & 17 & $11.4 \pm 7.3$ & $7.7-15.2$ \\
\hline $1+2$ & 46 & $16.0 \pm 10.1^{\mathrm{c}}$ & $16.0-19.0$ & 39 & $10.6 \pm 9.7$ & $7.5-13.8$ \\
\hline \multicolumn{7}{|c|}{ XPD rs 13181} \\
\hline 0 & 32 & $16.7 \pm 10.8$ & $12.8-20.6$ & 15 & $11.6 \pm 7.7$ & $7.3-15.8$ \\
\hline 1 & 27 & $16.4 \pm 10.7^{\mathrm{d}}$ & $12.1-20.6$ & 33 & $9.8 \pm 8.5$ & $6.7-12.8$ \\
\hline 2 & 18 & $15.0 \pm 9.8$ & $10.1-19.9$ & 8 & $14.0 \pm 12.8$ & $3.3-24.7$ \\
\hline \multicolumn{7}{|c|}{ XRCC1 rs861539 } \\
\hline 0 & 31 & $17.3 \pm 12.3^{\mathrm{e}}$ & $12.8-21.8$ & 22 & $9.6 \pm 8.8$ & $5.7-13.5$ \\
\hline $1+2$ & 46 & $15.4 \pm 9.0$ & $12.8 \pm 18.1$ & 34 & $11.6 \pm 9.1$ & $8.5-14.8$ \\
\hline \multicolumn{7}{|c|}{ XRCC3 rs861539 } \\
\hline 0 & 23 & $18.3 \pm 9.9^{\mathrm{f}}$ & $14.0-22.6$ & 23 & $11.8 \pm 9.8$ & $7.6-16.0$ \\
\hline $1+2$ & 54 & $15.3 \pm 10.6^{\mathrm{g}}$ & $12.4-18.2$ & 31 & $9.7 \pm 8.4$ & $6.6-12.7$ \\
\hline \multicolumn{7}{|c|}{ PARP1 rs1136410 } \\
\hline 0 & 55 & $17.3 \pm 10.5^{\mathrm{h}}$ & $14.4-20.1$ & 33 & $11.3 \pm 8.9$ & $8.2-14.5$ \\
\hline $1+2$ & 22 & $13.5 \pm 9.9$ & $9.1-17.9$ & 23 & $10.4 \pm 8.8$ & $6.2-14.2$ \\
\hline \multicolumn{7}{|c|}{ MGMT rs12917 } \\
\hline 0 & 56 & $18.2 \pm 10.6^{\mathrm{i}}$ & $15.3-21.0$ & 39 & $11.1 \pm 9.2$ & $8.1-14.1$ \\
\hline $1+2$ & 21 & $11.0 \pm 8.0$ & $7-3-14.6$ & 17 & $10.2 \pm 8.7$ & $5.8-14.7$ \\
\hline
\end{tabular}

With regard to $X R C C 3$, MNi frequency was also significantly higher in IR exposed homozygous SNP pooled with heterozygous, compared to controls with the same pooled genotype. In addition, MNi frequency was also significantly higher in IR exposed heterozygous for $A P E X I$ and $X P D$ rs13181. Regarding XPD rs1799793, we also observed a significantly higher MNi frequency in homozygous SNP pooled with heterozygous, compared to controls with the same pooled genotype. Concerning the APEX1 genotype, we also observed an influence on NB frequency. In particular, significantly lower NBs frequency was observed in IR exposed workers homozygous SNP compared to controls with the same genotype (Table 9).

\section{DISCUSSION}

CBMN assay has already shown to be a reliable biomarker in the evaluation of IR exposure in different settings, including radiotherapy and occupational and accidental environmental exposure (17). The strength and novelty of the present study lies in its investigation of biomarkers of the CBMN cytome assay, which includes NPBs and NBs in addition to MNi. To the best of our knowledge, this is the first study to analyse NPBs and NBs in individuals occupationally exposed to IR-low doses. The analysis of NPBs and NBs in lymphocytes has become increasingly important for their sensitivity in revealing chromosomal damage in humans. The results of our study showed that MNi frequency was significantly higher in the IR exposed workers compared to controls. The significance was unlikely to be related to differences in age, sex, and smoking within the two groups, as the multivariate analysis showed that MNi frequency was significantly influenced by IR exposure. This finding confirms the reliability of the MNi frequency as biological dosimetry in population occupationally exposed to low doses of IR, as shown in several earlier cytogenetic studies $(9,10,18-23)$. To date, none of the studies on IR occupationally exposed workers have included the analysis of NPBs and NBs. Surprisingly, in our study these biomarkers were higher in controls compared to IR exposed workers, however the differences were small and statistically not significant. None of the occupationally exposed subjects studied here had ever exceeded the permitted radiation limit for occupational exposure, recommended by the International Commission on Radiological Protection (ICRP). The lack of knowledge of the IR dose equivalent to the whole body (external wholebody dose equivalent, $H w b$ ), accumulated over the entire working-life period may represent a limitation of the present study. On the other hand, most studies to date have failed 
Table 9 Mean NB frequencies in the study population subdivided by exposure status and genotype distribution

\begin{tabular}{|c|c|c|c|c|c|c|}
\hline \multirow[b]{2}{*}{ Gene* } & \multicolumn{3}{|c|}{ Exposed $(n=77)$} & \multicolumn{3}{|c|}{ Controls $(n=56)$} \\
\hline & Subject (n) & Mean \pm SD & $95 \%$ CI & Subject (n) & Mean \pm SD & $95 \%$ CI \\
\hline \multicolumn{7}{|c|}{ APEX1 rs1130409 } \\
\hline 0 & 26 & $1.5 \pm 2.0$ & $0.7-2.3$ & 19 & $1.2 \pm 1.9$ & $0.3-2.1$ \\
\hline 1 & 35 & $1.9 \pm 2.5$ & $1.1-2.8$ & 27 & $2.0 \pm 2.6$ & $1.0-3.1$ \\
\hline 2 & 16 & $1.6 \pm 3.8^{\mathrm{a}}$ & $0.6-3.8$ & 10 & $3.0 \pm 3.1$ & $0.8-5.2$ \\
\hline \multicolumn{7}{|c|}{ hOGG1 rs1052133 } \\
\hline 0 & 38 & $1.4 \pm 2.3$ & $0.7-2.2$ & 42 & $1.8 \pm 2.6$ & $1.0-2.6$ \\
\hline $1+2$ & 39 & $1.9 \pm 2.9$ & $1.0-2.9$ & 14 & $2.3 \pm 2.5$ & $0.8-3.7$ \\
\hline \multicolumn{7}{|c|}{ XPD rs 1799793} \\
\hline 0 & 31 & $1.7 \pm 1.7$ & $1.1-2.3$ & 17 & $3.0 \pm 3.4$ & $1.2-4.8$ \\
\hline $1+2$ & 46 & $1.7 \pm 3.1$ & $0.8-2.6$ & 39 & $1.4 \pm 1.9$ & $0.8-2.0$ \\
\hline \multicolumn{7}{|c|}{ XPD rs13181 } \\
\hline 0 & 32 & $1.9 \pm 1.7$ & $1.2-25$ & 15 & $2.6 \pm 3.8$ & $0.5-4.7$ \\
\hline 1 & 27 & $1.6 \pm 3.3$ & $0.3-2.9$ & 33 & $1.7 \pm 1.8$ & $1.0-2.3$ \\
\hline 2 & 18 & $1.5 \pm 3.0$ & $0.1-3.0$ & 8 & $1.6 \pm 2.1$ & $0.1-3.4$ \\
\hline \multicolumn{7}{|c|}{ XRCC1 rs861539 } \\
\hline 0 & 31 & $1.3 \pm 1.9$ & $0.6-2.0$ & 22 & $2.1 \pm 3.2$ & $0.7-3.5$ \\
\hline $1+2$ & 46 & $2.0 \pm 3.0$ & $0.7-1.8$ & 34 & $1.8 \pm 2.0$ & $1.1-2.5$ \\
\hline \multicolumn{7}{|c|}{ XRCC3 rs861539 } \\
\hline 0 & 23 & $1.6 \pm 3.2$ & $0.2-3.0$ & 23 & $2.0 \pm 2.3$ & $1.0-2.9$ \\
\hline $1+2$ & 54 & $1.8 \pm 2.4$ & $1.1-2.4$ & 31 & $2.0 \pm 2.8$ & $0.9-3.0$ \\
\hline \multicolumn{7}{|c|}{ PARP1 rs1136410 } \\
\hline 0 & 55 & $1.9 \pm 2.8$ & $1.1-2.7$ & 33 & $2.5 \pm 3.0$ & $1.5-3.6$ \\
\hline $1+2$ & 22 & $1.2 \pm 2.0$ & $0.4-2.1$ & 23 & $1.0 \pm 1.4^{\mathrm{b}}$ & $0.5-1.6$ \\
\hline \multicolumn{7}{|c|}{ MGMT rs12917 } \\
\hline 0 & 56 & $1.9 \pm 2.9$ & $1.1-2.7$ & 39 & $1.7 \pm 2.4$ & $0.9-2.5$ \\
\hline $1+2$ & 21 & $1.2 \pm 1.6$ & $0.5-2.0$ & 17 & $2.4 \pm 2.9$ & $0.3-2.8$ \\
\hline
\end{tabular}

$* 0=$ homozygous wild-type (wt); $1=$ Heterozygous $(H E) ; 2=$ homozygous polymorphic (SNP)

${ }^{a}$ Significantly different from controls with the same genotypes (Wilcoxon test, $\mathrm{P}=0.041$ )

${ }^{b}$ Significantly different from homozygous wild-type controls (Kruskal-Wallis test, $\mathrm{P}=0.044$ )

Table 10 Mean NPB frequencies in the study population subdivided by exposure status and genotype distribution

\begin{tabular}{|c|c|c|c|c|c|c|}
\hline & \multicolumn{3}{|c|}{ Exposed $(n=77)$} & \multicolumn{3}{|c|}{ Controls $(n=56)$} \\
\hline Gene* & Subject (n) & Mean \pm SD & $95 \% \mathrm{CI}$ & Subject (n) & Mean \pm SD & $95 \%$ CI \\
\hline \multicolumn{7}{|c|}{ APEX1 rs1130409 } \\
\hline 0 & 26 & $1.0 \pm 1.8$ & $0.3-1.7$ & 19 & $0.7 \pm 1.4$ & $0.1-1.4$ \\
\hline 1 & 35 & $1.0 \pm 1.4$ & $0.5-1.4$ & 27 & $1.7 \pm 2.2$ & $0.8-2.5$ \\
\hline 2 & 16 & $0.8 \pm 1.5$ & $0.1-1.6$ & 10 & $1.8 \pm 2.3$ & $0.1-3.5$ \\
\hline \multicolumn{7}{|c|}{ hOGG1 rs1052133 } \\
\hline 0 & 38 & $0.7 \pm 1.1$ & $0.4-1.1$ & 42 & $1.1 \pm 1.8$ & $0.6-1.7$ \\
\hline $1+2$ & 39 & $1.2 \pm 1.9$ & $0.6-1.8$ & 14 & $2.1 \pm 2.6$ & $0.6-3.6$ \\
\hline \multicolumn{7}{|c|}{ XPD rs 1799793} \\
\hline 0 & 31 & $0.7 \pm 1.0$ & $0.3-1.1$ & 17 & $1.4 \pm 2.3$ & $0.2-2.6$ \\
\hline $1+2$ & 46 & $1.1 \pm 1.8$ & $0.6-1.7$ & 39 & $1.4 \pm 1.9$ & $0.7-2.0$ \\
\hline \multicolumn{7}{|c|}{ XPD rs13181 } \\
\hline 0 & 32 & $1.0 \pm 1.8$ & $0.4-1.7$ & 15 & $1.5 \pm 2.4$ & $0.1-2.8$ \\
\hline 1 & 27 & $0.6 \pm 0.9$ & $0.3-1.0$ & 33 & $1.3 \pm 1.8$ & $0.7-1.9$ \\
\hline 2 & 18 & $1.3 \pm 1.8$ & $0.4-2.2$ & 8 & $1.5 \pm 2.5$ & $0.1-3.5$ \\
\hline \multicolumn{7}{|c|}{ XRCC1 rs861539 } \\
\hline 0 & 31 & $0.7 \pm 1.0$ & $0.3-2.1$ & 22 & $1.6 \pm 2.6$ & $0.5-2.8$ \\
\hline $1+2$ & 46 & $1.1 \pm 1.8$ & $0.6-1.6$ & 34 & $1.2 \pm 1.6$ & $0.7-1.8$ \\
\hline \multicolumn{7}{|c|}{ XRCC3 rs861539 } \\
\hline 0 & 23 & $1.3 \pm 2.0$ & $0.4-2.1$ & 23 & $1.5 \pm 2.3$ & $0.5-2.5$ \\
\hline $1+2$ & 54 & $0.8 \pm 1.2$ & $0.5-1.2$ & 31 & $1.3 \pm 1.9$ & $0.6-2.0$ \\
\hline \multicolumn{7}{|c|}{ PARP1 rs1136410 } \\
\hline 0 & 55 & $1.2 \pm 1.7$ & $0.7-1.6$ & 33 & $1.8 \pm 2.5$ & $1.0-2.7$ \\
\hline $1+2$ & 22 & $0.4 \pm 0.8^{\mathrm{a}}$ & $0.1-0.8$ & 23 & $0.7 \pm 0.8$ & $0.4-1.1$ \\
\hline \multicolumn{7}{|c|}{ MGMT rs12917 } \\
\hline 0 & 56 & $1.1 \pm 1.5$ & $0.6-1.5$ & 39 & $1.3 \pm 1.9$ & $0.7-1.9$ \\
\hline $1+2$ & 21 & $0.7 \pm 1.5$ & $0.1-1.3$ & 17 & $1.5 \pm 2.4$ & $0.3-2.8$ \\
\hline
\end{tabular}


to find any association between chromosome damage and $H w b$ accumulated after chronic exposure to low doses (9, $19,20,22,24,25)$. From this point of view, the years the workers were occupationally exposed to IR may represent an attempt to overcome the limits associated with the use of dosimeters. Positive correlation of MNi frequency and exposure duration has been confirmed in previous studies $(23,26)$, with a reported elevated high risk of cancer in medical X-ray workers as their service duration increased (2). Our IR exposed group demonstrated a clear relation between $\mathrm{MNi}$ and NB frequencies, that is, an increase of 0.4 and 0.07 in the number of MNi and NBs respectively, per 1 year of IR occupational exposure.

Age, sex, and smoking status are common confounding factors known to affect MNi frequency, whereas information on NBs and NPBs are limited. Despite the relatively small sample size, our data confirm the effect of aging on $\mathrm{MNi}$ frequency in all of the studied groups - i.e. exposed, controls and overall population. The same age dependent effect was seen for NBs, a finding that might not be surprising as the nuclear budding process has emerged as another unique mechanisms of MNi formation. NBs are also associated with the alteration of DNA stability, with evidence that these structures contain entire or fragments of chromosomes $(6$, 27). Our study is in agreement with an international collaborative study on pooled data from 25 laboratories that confirmed the impact of sex on MNi frequencies among subjects involved in occupational and environmental surveys (28), although in our case female subjects differed significantly from the male only in the control group. In the entire studied population, men had a higher NPB frequency, as in another study on healthy volunteers (29), but the knowledge of the effect of confounding factor on NPBs frequencies is not as extensive as on MNi. Generally, the effects of smoking on DNA damage in individuals exposed to IR are still unclear, with opposite results $(9,20,24,26$, 30, 31). In IR exposed subjects, smoking habits were associated with increased $\mathrm{MNi}$ frequency, which is in agreement with previous studies $(20,30)$, but there was a significantly decreased MNi frequency in the control group. Interestingly, NB frequency was significantly decreased both in the IR exposed workers and in the overall population. In our study population, none of the individuals reported being heavy smokers ( $\geq 30$ cigarettes per day), which made it impossible to further study the potential increase of genetic damage, primarily MNi. It has been shown that MNi frequency among occupationally and environmentally exposed individuals is influenced only in non-exposed heavy smokers (32) and slightly reduced in smokers exposed to genotoxic agents, with two possible explanations: appearance of apoptotic/necrotic cells due to cigarette smoke damage that would not be detected in the CBMN assay $(20,29)$ and possible adaptive response stimulation caused by the intake of a few cigarettes per day, causing a lowering in MN frequency (29).
Another critical consideration is the cellular response to IR low doses. Exposure is a complex mechanism, leading to the activation of multiple signal transduction pathways, which besides DNA repair include apoptosis, proliferation, inflammation, and genomic instability. Therefore, different genes, belonging to these different pathways, and characterised by several polymorphisms, may contribute to the individual genome sensitivity in IR exposed subjects (8-10, 33-36). Genotype analysis revealed an association between all of the investigated polymorphisms and $\mathrm{MNi}$ frequency, while only the APEX1 polymorphism was associated with NB frequency. With regard to the $X R C C 3$ polymorphism, the effect on $\mathrm{MNi}$ is unclear. Both genotype groups in the IR exposed group had significantly higher $\mathrm{MNi}$ frequencies compared to controls with the same genotypes, with no difference within the group. This hypothesis corroborates in vitro studies that reported an association between increased sensitivity to IR in human lymphocytes and SNPs in DNA repair genes $(7,36)$. It is feasible that gene-gene interactions may influence DNA damage in response to dose; however, the reduction in sample sizes, as a consequence of successive categorization, even further limits the already weak statistical power (due to small sample size). It is undoubtedly possible that some of the associations become significant by chance, due to the inadequate statistical power. However, this does not rule out an association between DNA repair gene polymorphisms and DNA damage frequency (36). Achieving a complete understanding of this interaction may be of great importance for implementing radiation protection and radiotherapy programmes $(37,38)$. In view of this, concomitant analysis of DNA damage and interindividual differences in DNA repair genes, due to the presence of polymorphisms, may represent a valuable multi-biomarker approach (39).

In conclusion, our group was the first to score $\mathrm{MNi}$, NBs, and NPBs in IR exposed workers. Clearly, the results obtained confirmed the genotoxic implication resulting from the occupational exposure to IR low doses. Moreover, we believe we have confirmed the value of the MNi frequency as a standard and powerful cytogenetic method for studying genotoxicity in populations exposed to IR low doses. Whether the cytome assay, meaning NBs and NPBs that were not found to be higher, could improve the predictive capacity of the assay to reveal genetic damage after chronic IR low dose exposure, remains to be determined. Obviously, before ruling out the usefulness of NB and NPB analysis in IR exposed individuals, it would be desirable to replicate the study on a larger population. Nevertheless, it might be interesting to apply the cytome assay in populations exhibiting different IR exposure levels. In particular, interventional cardiologists are currently exposed to a significantly radiation risk compared to other occupational IR exposed individuals. 


\section{Acknowledgement}

This study was partly supported by the Ministry of Science, Education and Sports of the Republic of Croatia (grant number 0022-0222148-2137). Dr Mirta Milić's visit to the University of Bologna was made possible thanks to a fellowship awarded by the Ministry of Science, Education and Sports of the Republic of Croatia. Corrado Zenesini and Muriel Musti were supported by a grant from Fondazione del Monte di Bologna e Ravenna. Gloria Ravegnini was supported by a grant from Fondazione Umberto Veronesi - Post-doctoral fellowship 2014. The funding agencies had no role in the study design, data collection and analysis, or preparation of the manuscript.

\section{Conflict of interest}

The authors declare that there is no conflict of interests regarding the publication of this paper.

\section{REFERENCES}

1. Berrington A, Darby SC, Weiss HA, Doll R. 100 years of observation on British radiologists: mortality from cancer and other causes 1897-1997. Br J Radiol 2001;74:507-19. doi: $10.1259 /$ bjr.74.882.740507

2. Wang JX, Zhang LA, Li BX, Zhao YC, Wang ZQ, Zhang JY, Aoyama T. Cancer incidence and risk estimation among medical X-ray workers in China. Health Phys 2002;82:45566. PMID: 11906134

3. Cardis E, Vrijheid M, Blettner M, Gilbert E, Hakama M, Hill C, Howe G, Kaldor D, Muirhead CR, Schubauer-Berigan M, Yoshimura T, Bermann F, Cowper G, Fix J, Hacker C, Heinmiller B, Marshall M, Thierry-Chef I, Utterback D, Ahn YO, Amoros E, Ashmore P, Auvinen A, Bae JM, Solano JB, Biau A, Combalot E, Deboodt P, Diez Sacristan A, Eklof M, Engels H, Engholm G, Gulis G, Habib R, Holan K, Hyvonen H, Kerekes A, Kurtinaitis J, Malker H, Martuzzi M, Mastauskas A, Monnet A, Moser M, Pearce MS, Richardson DB, Rodriguez-Artalejo F, Rogel A, Tardy H, TelleLamberton M, Turai I, Usel M, Veress K. Risk of cancer after low doses of ionising radiation: retrospective cohort study in 15 countries. Br Med J 2005;331:77-80. doi: 10.1136/ bmj.38499.599861.E0

4. Metz-Flamant C, Samson E, Caër-Lorho S, Acker A, Laurier D. Leukemia risk associated with chronic external exposure to ionizing radiation in a French cohort of nuclear workers. Radiat Res 2012;178:489-98. doi: 10.1667/RR2822.1

5. Kopjar N, Kašuba V, Milić M, Rozgaj R, Želježić D, Gajski G, Mladinić M, Garaj-Vrhovac V. Normalne i granične vrijednosti mikronukleus-testa na limfocitima periferne krvi u ispitanika opće populacije Republike Hrvatske [Normal and cut-off values of the cytokinesis-block micronucleus assay on peripheral blood lymphocytes in the Croatian general population, in Croatian]. Arh Hig Rada Toksikol 2010:61:219-34. doi: 10.2478/10004-1254-61-2010-2027

6. Fenech M. Cytokinesis-block micronucleus cytome assay. Nat Protoc 2007;2:1084-104. doi: 10.1038/nprot.2007.77

7. Hu JJ, Smith TR, Miller MS, Mohrenweiser HW, Golden A, Case LD. Amino acid substitution variants of $A P E 1$ and
$X R C C 1$ genes associated with ionizing radiation sensitivity. Carcinogenesis 2001;22:917-22. doi: 10.1093/ $\operatorname{carcin} / 22.6 .917$

8. Aka P, Mateuca R, Buchet JP, Thierens H, Kirsch-Volders $\mathrm{M}$. Are genetic polymorphisms in OGG1, XRCC1 and XRCC3 genes predictive for the DNA strand break repair phenotype and genotoxicity in workers exposed to low dose ionising radiations? Mutat Res 2004;556:169-81. PMID: 15491645

9. Angelini S, Kumar R, Carbone F, Maffei F, Cantelli-Forti G, Violante FS, Lodi V, Curti S, Hemminki K, Hrelia P. Micronuclei in humans induced by exposure to low level of ionizing radiation: influence of polymorphims in DNA repair genes. Mutat Res 2005;570:105-17. PMID: 15680408

10. Andreassi MG, Foffa I, Manfredi S, Botto N, Cioppa A, Picano E. Genetic polymorphisms in XRCC1, OGG1, APE1 and XRCC3 DNA repair genes, ionizing radiation exposure and chromosomal DNA damage in interventional cardiologists. Mutat Res 2009;666:57-63. doi: 10.1016/j. mrfmmm.2009.04.003

11. Kapka L, Baumgartner A, Siwińska E, Knudsen LE, Anderson D, Mielzyńska D Environmental lead exposure increases micronuclei in children. Mutagenesis 2007;22:2017. doi: 10.1093/mutage/gem004

12. Fenech M, Chang WP, Kirsch-Volders M, Holland N, Bonassi S, Zeiger E. HUMN project: detailed description of the scoring criteria for the cytokinesis-block micronucleus assay using isolated human lymphocyte cultures. Mutat Res 2003;534:65-75. PMID: 12504755

13. Eastmond DA, Tucker JD. Kinetochore localization in micronucleated cytokinesis-blocked Chinese hamster ovary cells: a new and rapid assay for identifying aneuploidyinducing agents. Mutat Res 1989;224:517-25. PMID: 2685592

14. Hu JJ, Mohrenweiser HW, Bell DA, Leadon SA, Miller MS. Symposium overview: genetic polymorphisms in DNA repair and cancer risk. Toxicol Appl Pharmacol 2002;185:64-73. PMID: 12460738

15. Godderis L, Aka P, Mateuca R, Kirsch-Volders M, Lison D, Veulemans H. Dose dependent influence of genetic polymorphisms on DNA damage induced by styrene oxide, ethylene oxide and gamma-radiation. Toxicology 2006;219:220-9. doi: 10.1016/j.tox.2005.11.021

16. Stata Corporation. Stata Statistical software, release 11. College Station, TX: stata Corporation; 2011.

17. Vral A, Fenech M, Thierens H. The micronucleus assay as a biological dosimeter of in vivo ionizing radiation exposure. Mutagenesis 2011;26:11-7. doi: 10.1093/mutage/geq078

18. Fučić A, Markučič D, Mijić A, Jazbec AM. Estimation of genome damage after exposure to ionizing radiation and ultrasound used in industry. Environ Mol Mutagen 2000;36:47-51. PMID: 10918359

19. Cardoso RS, Takahashi-Hyodo S, Peitl P Jr, Ghilardi-Neto T, Sakamoto-Hojo ET. Evaluation of chromosomal aberrations, micronuclei, and sister chromatid exchanges in hospital workers chronically exposed to ionizing radiation. Teratog Carcinog Mutagen 2001;21:431-9. PMID: 11746256

20. Maffei F, Angelini S, Cantelli-Forti G, Lodi V, Violante FS, Mattioli S, Hrelia P. Micronuclei frequency in hospital workers occupationally exposed to low levels of ionizing radiation: influence of smoking status and other factors. Mutagenesis 2002;17:405-9. doi: 10.1093/mutage/17.5.405 
21. Hadjidekova VB, Bulanova M, Bonassi S, Neri M. Micronucleus frequency is increased in peripheral blood lymphocytes of nuclear power plant workers. Radiat Res 2003;160:684-90. PMID: 14640795

22. Zakeri F, Hirobe T. A cytogenetic approach to the effects of low levels of ionizing radiations on occupationally exposed individuals. Eur J Radiol 2010;73:191-5. doi: 10.1016/j. ejrad.2008.10.015

23. Sakly A, Gaspar JF, Kerkeni E, Silva S, Teixeira JP, Chaari $\mathrm{N}$, Cheikh HB. Genotoxic damage in hospital workers exposed to ionizing radiation and metabolic gene polymorphisms. J Toxicol Environ Health A 2012;75:934-46. doi: 10.1080/15287394.2012.690710

24. Maluf SW, Passos DF, Bacelar A, Speit G, Erdtmann B. Assessment of DNA damage in lymphocytes of workers exposed to X-radiation using the micronucleus test and the comet assay. Environ Mol Mutagen 2001;38:311-5. doi: 10.1002/em.10029

25. Thierens H, Vral A, Barbé M, Meijlaers M, Baeyens A. Chromosomal radiosensitivity study of temporary nuclear workers and the support of the adaptive response induced by occupational exposure. Int J Rad Biol 2002;78:1117-26. doi: 10.1080/0955300021000034710

26. Sari-Minodier I, Orsiere T, Auquier P, Martin F, Botta A Cytogenetic monitoring by use of the micronucleus assay among hospital workers exposed to low doses of ionising radiation. Mutat Res 2007;629:111-21. PMID: 17428723

27. Dutra A, Pak E, Wincovitch S, John K, Poirier MC, Olivero OA. Nuclear bud formation: a novel manifestation of Zidovudine genotoxicity. Cytogen Genome Res 2010;128:105-10. doi: 10.1159/000298794

28. Bonassi S, Fenech M, Lando C, Lin YP, Ceppi M, Chang WP, Holland N, Kirsch-Volders M, Zeiger E, Ban S, Barale R, Bigatti MP, Bolognesi C, Jia C, Di Giorgio M, Ferguson LR, Fucic A, Lima OG, Hrelia P, Krishnaja AP, Lee TK, Migliore L, Mikhalevich L, Mirkova E, Mosesso P, Müller WU, Odagiri Y, Scarffi MR, Szabova E, Vorobtsova I, Vral A, Zijno A. HUman MicroNucleus project: international database comparison for results with the cytokinesis-block micronucleus assay in human lymphocytes: I effects of laboratory protocol, scoring criteria, and host factors on the frequency of micronuclei. Environ Mol Mutagen 2001;37:3145. PMID: 11170240

29. Donmez-Altuntas H, Bitgen N. Evaluation of the genotoxicity and cytotoxicity in the general population in Turkey by use of the cytokinesis-block micronucleus cytome assay. Mutat Res 2012;748:1-7. doi: 10.1016/j.mrgentox.2012.05.013

30. Dias FL, Antunes LM, Rezende PA, Carvalho FE, Silva CM, Matheus JM, Oliveira JV Jr, Lopes GP, Pereira GA, Balarin MA. Cytogenetic analysis in lymphocytes from workers occupationally exposed to low levels of ionizing radiation.
Environ Toxicol Pharmacol 2007;23:228-33. doi: 10.1016/j. etap.2006.10.003

31. Eken A, Aydin A, Erdem O, Akay C, Sanal HT, Soykut B, Sayal A, Somuncu I. Cytogenetic analysis of peripheral blood lymphocytes of hospital staff occupationally exposed to low doses of ionizing radiation. Toxicol Ind Health 2010;26:27380. doi: 10.1177/0748233710365693

32. Bonassi S, Neri M, Lando C, Ceppi M, Lin Y, Chang WP, Holland N, Kirsch-Volders M, Zeiger E, Fenech M; The HUMN collaborative group. Effect of smoking habits on the frequency of micronuclei in human lymphocytes: results from the Human MicroNucleus project. Mutat Res 2003;543:155-66. PMID: 12644185

33. Damiola F, Byrnes G, Moissonnier M, Pertesi M, Deltour I, Fillon A, Le Calvez-Kelm F, Tenet V, McKay-Chopin S, McKay JD, Malakhova I, Masyakin V, Cardis E, Lesueur F, Kesminiene A. Contribution of ATM and FOXE1 (TTF2) to risk of papillary thyroid carcinoma in Belarusian children exposed to radiation. Int J Cancer 2014;134:1659-68. doi: $10.1002 /$ ijc. 28483

34. Salnikova L, Chumachenko A, Belopolskaya O, Rubanovich A. Correlations between DNA polymorphism and frequencies of gamma-radiation induced and spontaneous cytogenetic damage. Health Phys 2012;103:37-41. doi: 10.1097/HP.0b013e3182231a9d

35. Cho YH, Kim YJ, An YS, Woo HD, Choi SY, Kang CM, Chung HW. Micronucleus-centromere assay and DNA repair gene polymorphisms in lymphocytes of industrial radiographers. Mutat Res 2009;680:17-24. doi: 10.1016/j. mrgentox.2009.08.007

36. Rzeszowska-Wolny J, Polanska J, Pietrowska M, Palyvoda O, Jaworska J, Butkiewicz D, Hancock R. Influence of polymorphisms in DNa repair genes XPD, XRCC1 and MGMT on DNA damage induced by gamma radiation and its repair in lymphocytes in vitro. Radiat Res 2005;164:13240. PMID: 16038584

37. Mohrenweiser HW, Wilson DM, Jones IM. Challenges and complexities in estimating both the functional impact and the disease risk associated with the extensive genetic variation in human DNA repair genes. Mutat Res 2003;526:93-125. PMID: 12714187

38. Roos WP, Binder A, Böhm L. Determination of the initial DNA damage and residual DNA damage remaining after 12 hours of repair in eleven cell lines at low doses of irradiation. Int J Radiat Biol 2000;76:1493-500. PMID: 11098852

39. Touil N, Aka PV, Buchet JP, Thierens H, Kirsch-Volders M. Assessment of genotoxic effects related to chronic low level exposure to ionizing radiation using biomarkers for DNA damage and repair. Mutagenesis 2002;17:223-32. PMID: 11971994 


\section{Polimorfizmi u genima za popravak DNA: poveznica s biomarkerima mikronukleus-testa u medicinskih radnika kronično izloženih niskim dozama ionizirajućeg zračenja}

Individualna osjetljivost na ionizirajuće zračenje rezultat je međudjelovanja samog izlaganja zračenju, oštećenja DNA nastalog prilikom tog izlaganja te samog popravka nastalog oštećenja. Veliki doprinos razlikama čine i polimorfizmi u genima za popravak DNA. U ovom radu istražili smo povezanost nastalih oštećenja DNA u obliku mikronukleusa (MN), jezgrinih pupova (NB) i nukleoplazmatskih mostova (NPB) s polimorfizmima jednog nukleotida (SNP) u genima za popravak DNK (APE1, hOGG1,XRCC1, XRCC3, XPD, PARP1, MGMT) koji sudjeluju u različitim mehanizmima popravka. Rezultati skupine od 77 medicinskih radnika kronično izloženih niskim dozama ionizirajućeg zračenja uspoređeni su s rezultatima skupine od 70 odgovarajućih kontrola. Izložena skupina imala je značajno veću učestalost MN-a $(16,2 \pm 10,4$ vs. $11.5 \pm 9.4 ; P=0,003$ ), a sama pojavnost oštećenja bila je neovisna o medijatornoj varijabli (kovarijati). Značajno više učestalosti MN nađene su u izloženoj skupini u homozigotnih nositelja divljeg tipa gena hOGG1, XRCC1, PARP1 i MGMT i u heterozigotnih nositelja gena $A P E X 1$ i $X P D$ (rs13181) u odnosu na kontrolnu skupinu istoga genotipa. Analiza genskih polimorfizama i citogenetička dozimetrija važna su dopuna osobnom dozimetrijskom nadzoru izloženih radnika.

KLJUČNE RIJEČI: genotipska analiza; jezgrini pupovi; mikronukleus; nukleoplazmatski mostovi; profesionalna izloženost 